\title{
Meningkatkan Kemampuan Menyelesaikan Soal Cerita Matematika melalui Pendekatan Matematika Realistik pada Murid Kelas V SD Hang Tua Makassar
}

\author{
Kristiawati \\ e-mail: kristiawatidahlan@yahoo.co.id
}

\begin{abstract}
Abstrak
Masalah utama dalam penelitian ini yaitu bagaimana menerapkan pendekatan matematika realistik untuk meningkatkan kemampuan menyelesaikan soal cerita matematika pada murid kelas V SD Hangtua. Penelitian ini bertujuan untuk meningkatkan kemampuan menyelesaikan soal cerita matematika pendekatan matematika realistik pada murid kelas V SD Hang Tua Makassar.

Jenis penelitian ini adalah penelitian tindakan kelas (Class Action Reaserch) yang terdiri dari dua siklus dimana pada siklus I dilaksanakan sebanyak empat kali pertemuan dan siklus II empat kali pertemuan. Prosedur penelitian meliputi perencanaan, pelaksanaan tindakan, observasi dan refleksi. Subjek dalam penelitian ini adalah murid kelas V SD Hang Tua Makassar sebanyak 30 orang.

Hasil penelitian menunjukkan bahwa pada siklus pertama yang tuntas secara individual dari 30 murid yaitu 12 orang murid atau 40\% yang memenuhi kriteria ketuntasan minimal (KKM) yaitu 65 atau berada pada kategori rendah. Secara klasikal belum terpenuhi karena nilai rata-rata diperoleh sebesar 64,2. Sedangkan pada siklus II dimana dari 30 murid terdapat 24 orang murid atau $80 \%$ telah memenuhi KKM yaitu 65 dan secara klasikal sudah terpenuhi yaitu nilai rata-rata yang diperoleh sebesar 76,5 atau berada dalam kategori tinggi.

Berdasarkan hasil penelitian tersebut di atas, dapat disimpulkan kemampuan menyelesaikan soal cerita matematika pada murid kelas V SD Hang Tua Makassar melalui pendekatan matematika realistik mengalami peningkatan.
\end{abstract}

Kata kunci: menyelesaikan soal cerita matematika, pendekatan matematika realistic

\section{PENDAHULUAN}

Mutu pendidikan banyak bergantung pada mutu guru dalam membimbing pembelajaran. Meningkatkan mutu metode mengajar harus mencari prinsip atau asas-asas didaktik yang tepat. Namun demikian, masih tetap dianggap bahwa mengajar itu merupakan seni yang banyak bergantung kepada bakat dan kepribadian guru. Tingkat kesulitan siswa dalam penguasaan materi dan menyelesaikan soal cerita masih sangat rendah.

Guru juga menyatakan bahwa kesulitan yang dihadapi oleh murid dalam menyelesaikan soal cerita matematika yaitu murid kurang mampu memahami fakta, pembuatan model matematika, penyelesaian model matematika, dan menafsirkan hasil yang diperoleh. Oleh karena itu, perlu mendapat perhatian dari semua pihak yang bergelut dalam bidang pendidikan, karena keberhasilan guru dalam mengajarkan soal cerita matematika ditentukan oleh tingkat kemampuan murid dalam menyelesaikan soal cerita. 
Oleh karena itu, ketepatan guru dalam memilih model pembelajaran akan berpengaruh terhadap hasil belajar murid. Namun, harapan tersebut belum sesuai dengan kenyataan yang ditemui di lapangan karena kebanyakan murid hanya menghafal materi pelajaran matematika yang telah di peroleh sehingga merupakan pengetahuan sementara, sehingga tingkat belajar kemampuan murid dalam menjelesaikan soal cerita masih rendah.

Pendekatan matematika realistik merupakan salah satu pendekatan pembelajaran matematika yang berorientasi pada murid, bahwa matematika harus dihubungkan secara nyata terhadap konsep kehidupan sehari-hari siswa ke pengalaman belajar yang berorientasi pada hal-hal yang real (nyata).

Dalam pendidikan matematika reaslistik, matematika disajikan sebagai suatu proses, sebagai kegiatan manusia, bukan sebagai produk jadi. Unsur menemukan kembali (reinvent) sangat penting. Bahan pelajaran disajikan melalui bahan yang sesuai dengan lingkungan murid. Pendekatan matematika realistik menekankan kepada konstruksi dari konteks benda-benda konkret sebagai titik awal bagi siswa guna memperoleh konsep matematika. Tentu saja tidak berarti bahwa pendekatan realistik harus selalu menggunakan masalah yang ada dalam kehidupan nyata. Yang terpenting adalah masalah matematika yang bersifat abstrak dapat diubah menjadi nyata dalam pikiran siswa.

Karakteristik pendekatan matematika realistik adalah menggunakan konteks dunia nyata, model-model, produksi dan kontruksi murid, interaktif, dan keterkaitan (intertwinment). Menurut Suherman dalam Susanto (2013:206) dalam pembelajaran matematika yang menggunakan model pendekatan matematika realistik ini menganut karakteristik, sebagai berikut:

(1) Didominasi oleh masalah-masalah dalam konteks, melayani dua hal yaitu sebagai sumber dan sebagai terapan konsep matematika; (2) Perhatian diberikan kepada pengembangan model-model, situasi, skema, dan simbol-simbol; (3) Sumbangan dari para siswa, sehingga dapat membuat pembelajaran menjadi konstruktif dan produktif; (4) Interaktif sebagai karakteristik dari proses pembelajaran matematika; (5) Intertwining (membuat jalinan) antartopik atau antarpokok bahasan atau antarstrand.

\section{a. Prinsip-Prinsip Pembelajaran Matematika Realistik}

Gravemeijer (Hamzah, 2004 : 139) mengemukakan bahwa terdapat tiga prinsip utama dari pembelajaran matematika matematika realistik, yaitu :

1. Guided Reinvention (menemukan kembali) atau progressive Mathematizing (matematisasi progresif) murid harus diberi kesempatan untuk mengalami proses yang 
sama dengan proses yang dilalui oleh para pakar matematika ketika menemukan konsep-konsep matematika.

2. Didactical Phenomology (fenomena didaktik): topik-topik matematika yang diajarkan berasal dari fenomena sehari-hari. Topik-topik ini disajikan atas dua pertimbangan, yaitu: melihat kemungkinan aplikasinya dan konribusinya untuk perkembangan matematika lanjut.

3. Self-developed Models (pengembangan model sendiri): model dibuat oleh murid sendiri sewaktu memecahkan soal-soal kontekstual. Pada awalnya murid akan menggunakan model pemecahan yang informal atau model dari situasi yang dikenal oleh murid. Dengan suatu proses generalisasi dan formalisasi, model tersebut akhirnya menjadi model yang formal.

Ketiga prinsip diatas dioperasionalkan (dijabarkan) dalam karakteristik pembelajaran matematika realistik yang menjiwai seluruh aktivitas murid dalam kegiatan pembelajaran.

\section{b. Langkah - langkah Pembelajaran Matematika Realistik}

Secara umum langkah-langkah pembelajaran matematika realistik dapat disajikan sebagai berikut:

1. Memahami masalah kontekstual

Yaitu guru memberikan masalah kontekstual dalam kehidupan sehari-hari kepada murid dan meminta murid untuk memahami masalah tersebut, serta memberi kesempatan kepada murid untuk menanyakan masalah yang belum di pahami. Karakteristik PMR yang muncul pada langkah ini adalah karakteristik pertama yaitu menggunakan masalah kontekstual sebagai titik tolak dalam pembelajaran, dan karakteristik keempat yaitu interaksi.

\section{Menjelaskan masalah kontekstual}

Pada bagian ini jika dalam memahami masalah murid mengalami kesulitan, maka guru menjelaskan situasi dan kondisi dari soal dengan cara memberikan petunjukpetunjuk atau berupa saran seperlunya, terbatas pada bagian-bagian tertentu dari permasalahan yang belum dipahami.

\section{Menyelesaikan masalah}

Murid mendeskripsikan masalah kontekstual, melakukan interpretasi aspek matematika yang ada pada masalah yang dimaksud, dan memikirkan strategi pemecahan 
masalah. Selanjutnya murid bekerja menyelesaikan masalah dengan caranya sendiri berdasarkan pengetahuan awal yang dimilikinya, sehingga dimungkinkan adanya perbedaan penyelesaian murid yang satu dengan yang lainnya. Guru mengamati, memotivasi, dan memberi bimbingan terbatas, sehingga siswa dapat memperoleh penyelesaian masalah-masalah tersebut. Karakteristik PMR yang muncul pada langkah ini yaitu karakteristik kedua menggunakan model.

4. Membandingkan jawaban

Guru meminta murid membentuk kelompok secara berpasangan dengan teman sebangkunya, bekerja sama mendiskusikan penyelesaian masalah-masalah yang telah diselesaikan secara individu (negosiasi, membandingkan, dan berdiskusi). Guru mengamati kegiatan yang dilakukan murid, dan memberi bantuan jika dibutuhkan. Dipilih kelompok berpasangan, dengan pertimbangan efisiensi waktu. Karena di sekolah tempat pelaksanaan ujicoba, menggunakan bangku panjang. Sehingga kelompok dengan jumlah anggota yang lebih banyak, membutuhkan waktu yang lebih lama dalam pembentukannya. Sedangkan kelompok berpasangan tidak membutuhkan waktu, karena siswa telah duduk dalam tatanan kelompok berpasangan. Setelah diskusi berpasangan dilakukan, guru menunjuk wakil-wakil kelompok untuk menuliskan masing-masing ide penyelesaian dan alasan dari jawabannya, kemudian guru sebagai fasilitator dan moderator mengarahkan siswa berdiskusi, membimbing siswa mengambil kesimpulan sampai pada rumusan konsep/prinsip berdasarkan matematika formal (idealisasi, abstraksi). Karakteristik PMR yang muncul yaitu interaksi.

\section{Menyimpulkan}

Dari hasil diskusi kelas, guru mengarahkan murid untuk menarik kesimpulan suatu rumusan konsep/prinsip dari topik yang dipelajari. Karakteristik PMR yang muncul pada langkah ini adalah adanya interaksi antar siswa dengan guru.

Dari hasil pemaparan di atas penulis melakukan penelitian yaitu "Meningkatkan Kemampuan Murid dalam Menyelesaikan Soal Cerita Matematika melalui Pendekatan Matematika Realistik".

\section{Metode Penelitian}




\section{A. Jenis Penelitian}

Jenis penelitian yang dilaksanakan adalah penelitian tindakan kelas (PTK) yang akan dilaksanakan dalam dua siklus. Salah satu model PTK yang sering digunakan di dalam bidang pendidikan adalah model Kurt Lewin, (Kunandar, 2008:43) mengemukakan bahwa "konsep inti yang diperkenalkan dalam satu siklus terdiri dari empat langkah yaitu: perencancanaan (Planning), Tindakan (Acting), Pengamatan (Observasi), Refleksi (Reflection)”. Sedangkan menurut Wallace (Kunandar, 2008:44) penelitian tindakan dilakukan dengan mengumpulkan data atau informasi secara sistematis tentang praktik keseharian dan menganalisisnya untuk dapat membuat keputusan-keputusan tentang praktik yang seharusnya dilakukan dimasa mendatang.

Instrumen penelitian merupakan salah satu unsur yang sangat penting dalam penelitian karena berfungsi sebagai alat atau sarana pengumpulan data.

Dari pengertian di atas instrumen penelitian tindakan kelas ini adalah sebagai berikut:

1. Lembar observasi, digunakan untuk memperoleh data mengenai aktivitas murid dalam mengikuti pembelajaran dengan menerapkan pendekatan matematika realistik.

2. Tes hasil belajar, tes hasil belajar ini disusun dalam bentuk tes uraian. Tes ini dimaksudkan untuk mengukur kemampuan murid dalam menyelesaikan soal cerita.

3. Dokumentasi.

\section{Hasil dan Pembahasan}

Hasil analisis penelitian yang dilakukan pada murid Kelas V SD Hang Tua Makassar pada proses pembelajaran Matematika dengan menerapkan pendekatan matematika realistik yang dilakukan dapat meningkatkan kemampuan menyelesaikan soal cerita Matematika murid.

Setelah dilaksanakan proses pembelajaran pada Siklus I dan Siklus II berakhir dilakukan evaluasi untuk menilai sejauh mana kemampuan murid dalam memahami materi yang telah dipelajari dengan menerapkan pendekatan matematika realistik. Dari hasil tes tersebut, perolehan nilai rata-rata hasil belajar murid Kelas V SD Hang Tua Makassar pada Siklus I sebesar 64,2\%, kemudian pada Siklus II mengalami peningkatan yang signifikan yaitu sebesar 76,5\%.

dua kali tes siklus, banyak murid yang tuntas secara perorangan pada siklus I adalah 12 murid meningkat menjadi 24 murid pada siklus II. Pada siklus I ketidaktuntasan belajar 18 murid dan berkurang menjadi 6 murid pada siklus II. 
Jadi, dapat simpulkan bahwa penerapan pendekatan matematika realistik efektif digunakan dalam pembelajaran khususnya pada mata pelajaran Matematika. Ini disebabkan karena penerapan pendekatan matematika realistik dapat meningkatkan rasa tanggung jawab murid terhadap pembelajaran dan tugasnya dan dapat meningkatkan hasil belajar murid, saling bekerja sama dalam diskusi untuk mempelajari materi yang ditugaskan. Selain itu, meningkatkan kemampuan bekerja sama dan bersosialisasi, melatih kepekaan diri, simpati pada variasi perbedaan sikap, tingkah laku selama bekerja, dan meningkatkan motivasi dan prestasi belajar.

\section{SIMAN DAN SARAN}

\section{A. SIMPULAN}

Berdasarkan hasil penelitian dapat disimpulkan bahwa setelah dilaksanakan pembelajaran pada Siklus I dan Siklus II mata pelajaran Matematika dengan menggunakan pendekatan matematika realistik dapat meningkatkan prestasi belajar dan kemampuan murid dalam menyelesaikan soal cerita matematika pada murid Kelas V SD Hang Tua Makassar.

Hasil yang diperoleh oleh murid pada Siklus I, yaitu nilai rata-rata di bawah nilai KKM untuk pelajaran Matematika yakni 64,2 berada pada kategori rendah sedangkan nilai KKM 65, murid yang tuntas belajar hanya sebanyak 12 orang dari 30 murid yaitu $40 \%$. Sedangkan hasil yang diperoleh oleh murid pada Siklus II, nilai rata-rata di atas nilai KKM untuk pelajaran Matematika yakni 75,5 berada pada kategori tinggi sedangkan nilai KKM 65 , murid yang tuntas belajar sebanyak 24 orang dari 30 murid yaitu $80 \%$.

Maka dapat disimpulkan bahwa peningkatan prestasi belajar murid dan kemampuan menyelesaikan soal cerita Matematika melalui pendekatan matematika realistik pada murid Kelas V SD Hang Tua Makassar pada Siklus I dan Siklus II mengalami peningkatan.

\section{B. SARAN}

Berdasarkan hasil pembahasan dan kesimpulan yang diperoleh dari penelitian ini, maka Penulis mengajukan beberapa saran sebagai berikut:

1. Untuk Guru agar dapat menerapkan pendekatan matematika realistik dalam mata pelajaran Matematika untuk meningkatkan kemampuan menyelesaikan soal cerita Matematika serta mengaktifkan siswa dalam proses pembelajaran Matematika.

2. Kepada peneliti berikutnya, yang akan mengkaji rumusan yang serupa diharapkan dapat mengembangkan penelitian ini dengan mengkaji tentang pendekatan matematika 
realistik secara lebih mendalam lagi. Dan dapat menjadikan hasil penelitian ini sebagai bahan perbandingan.

\section{DAFTAR PUSTAKA}

Abdulbasir. 1988. Evaluasi Pendidikan. Surabaya: Airlangga University Press.

Agus, R. Sertawan, Hardjana. 1992. Kiat Sukses Studi di Perguruan Tinggi. Bandung: Angkasa.

Conny. 1990. Memupuk Bakat dan Kreatifitas Siswa Sekolah Menengah. Jakarta: Gramedia.

Dimyati. 1994. Belajar Pembelajaran. Jakarta: Depdikbud.

Hamalik, Oemar. 1983. Metode Mengajar dan Kesulitan Belajar. Bandung: Tarsito.

Syah, Muhibbin. 1999. Psikologi Belajar. Jakarta: Universitas Indonesia.

Nasution. 1982. Berbagai Pendekatan dalam Proses Belajar Mengajar. Jakarta: Bharatama Karya Aksara.

Ruseffendi, E. T. 1980. Pengajaran Matematika Modern untuk Orang Tua Murid, Guru dan $S P G$. Bandung: Tarsito.

Sudjana, Nana. 2002. Penilaian Hasil Proses Belajar Mengajar. Bandung: Remaja Rosdakarya.

Suwarno. 1992. Pengantar Umum Pendidikan. Jakarta: Rineka Cipta.

Usman. 1993. Menjadi Guru Profesional. Bandung: Remaja Rosdakarya.

Winkel, W.S. 1991. Psikologi Pengajaran. Jakarta: Raja Grasindo Persada. 